\title{
Adjusting to Skill Shortages in Australian SMEs ${ }^{\#}$
}

\author{
Joshua Healy $^{1}$, Kostas Mavromaras ${ }^{1,2}$ and Peter J. Sloane ${ }^{1,2,3}$ \\ ${ }^{1}$ National Institute of Labour Studies, Flinders University, Adelaide, Australia \\ ${ }^{2}$ Institute for the Study of Labor (IZA), Bonn, Germany \\ ${ }^{3}$ Swansea University, United Kingdom
}

\author{
Corresponding author \\ Joshua Healy \\ National Institute of Labour Studies \\ Flinders University \\ GPO Box 2100 \\ Adelaide SA 5001 \\ Australia \\ joshua.healy@flinders.edu.au
}

\footnotetext{
\# This paper draws from a study undertaken for the National Centre for Vocational Education Research (NCVER) by the National Institute of Labour Studies, Flinders University. See Healy, J., Mavromaras, K., and Sloane, P.J., 2011, Skill Shortages: Prevalence, Causes, Remedies and Consequences for Australian Businesses, NCVER, Adelaide. The authors share equal first authorship, and gratefully acknowledge funding received from the National Vocational Education and Training Research and Evaluation (NVETRE) Program.
} 


\title{
Adjusting to Skill Shortages in Australian SMEs
}

\begin{abstract}
Skill shortages are often portrayed as a major problem for advanced economies, yet there is surprisingly little empirical evidence about how firms adjust to skill shortages and their associated effects on firm performance. This paper provides new evidence from the Business Longitudinal Database, an Australian dataset with unusually rich information on the causes and consequences of skill shortages in small and medium-sized enterprises. We document the range of alternative strategies that firms adopt when responding to skill shortages, and show that certain types of adaptation are utilised in some cases and not in others, depending on the type of shortage encountered and other attributes of the firm. Further, we show that certain types of skill shortage are more likely to be long-lasting and difficult to resolve, while others are alleviated relatively quickly with minimal adjustment. Our findings yield lessons for the skill utilisation strategies of firms, and for the labour market policies of governments.
\end{abstract}

JEL codes: J0, J20, J23, J24 


\section{Introduction}

Employers often refer to hiring difficulties for suitably qualified workers, including in slack labour market conditions when labour is comparatively abundant. In some cases, employers may equate a 'skill shortage' with an inability to attract labour at current wage rates, or with skill gaps or skill deficiencies that are mainly a result of training inadequacies (Bosworth 1993; Green et al. 1998). There remains relatively little empirical research on the prevalence and causes of skill shortages and, particularly, on their consequences for firm behaviour and for firm performance. As Cappelli (2014) puts it, in relation to the US experience: 'It is difficult to think of a labour market issue where academic research...has played such a small role... where the quality of evidence and discussion has been so poor, and where the stakes are potentially so large'. Even in Australia, where the aggregate unemployment rate is relatively low, and where media reports of skill shortages are commonplace, academic work on the topic also remains sparse. Definitional problems, and a lack of quality representative statistics, have discouraged empirical inquiry into an otherwise important topic for labour economists and policy-makers.

In this paper, we make use of a novel Australian panel dataset, the Australian Bureau of Statistics’ (ABS) Business Longitudinal Database (BLD), to study the behaviour of smalland medium-sized enterprises (SMEs) as they confront and adjust to skill shortages. The BLD contains a large sample of SMEs, each with up to 200 employees; such firms provide the majority of Australian employment (ABS 2013). The BLD is a primarily survey-based data collection, but it is usefully augmented by Australian Tax Office (ATO) administrative data on several aspects of firm performance. We utilise the first three annual waves (2004-05 to 2006-07) of the BLD, which cover a period when Australia experienced strong economic growth and showed several signs of labour market overheating. The average unemployment 
rate was 4.9 per cent - the lowest since the 1970s (ABS 2011). The BLD thus provides us with an excellent source of data for studying how SMEs operating in tight labour market conditions deal with skill shortages, enabling us to make several novel contributions to the empirical literature.

The paper uses appropriate econometric techniques, to investigate: (i) the determinants of different types of skill shortages, (ii) the response strategies that firms use to relieve skill shortages, and (iii) the short-term consequences of skill shortages for firm performance. What sets this paper apart from much of the existing literature is our ability to investigate each phase of the skill shortage 'lifecycle', starting with their causes, continuing with the responses they induce, and concluding with their consequences for firm performance. We develop a distinction between simple and complex skill shortages, and we demonstrate its empirical importance for firms' responses and subsequent performance. The main contributions of the paper are as follows.

First, we begin by identifying the determinants of skill shortages and the range of alternative strategies that firms may adopt when responding to them. We then study the circumstances in which these alternative response strategies are utilised. To date, little has been written about firms’ responses to skill shortages, as distinct from the factors that determine whether or not a shortage exists. Thus, the first contribution of the paper is to demonstrate that certain types of responses to skill shortages are utilised in some circumstances and not in others, and that the responses of employers are conditional on the type of shortage their firm encounters, along with other attributes of their firm.

Second, we analyse what happens to skill shortages reported by firms in the years after these are first reported. We find that there are marked differences in longevity: certain types of skill shortage tend to be longer-lasting, while others tend to be resolved quickly with minimal 
adjustment. These results carry a range of practical implications for how managers and policy-makers should gather information and act in the face of skill shortages.

Third, we consider the relationship between skill shortages and firm performance. We analyse firm sales data from the ATO, along with differences in the timing and duration of skill shortages, to test this relationship. We find no significant evidence that shortages are harmful to sales performance and some evidence to the contrary.

Finally, our analysis focuses on SMEs, a distinctive and under-studied group of firms. These firms provide the majority of Australian jobs, but they have received relatively little attention in skill-shortage research, due to an emphasis on larger enterprises. The analytical framework that we develop and our results yield lessons for the skill-utilisation strategies of SMEs and for the labour market policies of governments. In both respects, our conclusions are relevant for countries other than Australia.

\section{Related Research}

We review the literature in relation to the objectives of the paper, first considering what constitutes a skill shortage, then the ways in which employers respond to them and, finally, the consequences of their presence. Although we recognise that the literature does not offer a unanimously accepted definition of skill shortage (see, for example: Watson, Johnson and Webb (2006), for the UK; Cappelli (2014), for the US; and Bellman and Hubler (2014), for Germany) we contend that useful progress can be made by studying how firms deal with selfreported skill shortages and what their apparent consequences are for firms’ performance. ${ }^{1}$

Australian literature on skill shortages has not been extensive. This is despite the pressures applied to the Australian labour market by the recent mining investment boom, reinforced by the limited impact of the global recession on the Australian economy and the prominence of 
Australian skilled migration policy. Junankar (2009) noted that real wages have increased more slowly than productivity growth in the areas of Australia most affected by miningrelated skill shortages. In addition, employers in these areas have continued to advertise vacancies for jobs that are temporary, often with irregular or unattractive shifts, and often requiring that the workers who are hired must provide their own equipment. Junankar (2009) concludes that it remains unclear why employers do not improve the attractiveness of their employment conditions when faced with skill shortages, and what alternative strategies they prefer. These questions are echoed by Cappelli (2005) for the US. Coelli and Wilkins (2008) note that these issues have been difficult to analyse in Australia, because of a lack of suitable representative data on employers.

The skill shortage concept implies a disequilibrium situation in which the demand for labour exceeds the supply of available workers at the ruling market wage. Thus, a case where an employer is not willing to pay the market wage is not a skill shortage, in the strictest sense. In practice, however, many studies of skill shortages rely on survey responses of employers, and there is much variability in how employers interpret the term 'shortage'. They may equate shortages with internal skill deficiencies, where existing workers have sub-optimal skills, or with skills gaps, where existing workers lack sufficient skills to do their jobs effectively (Green et al. 1998; Shah and Burke 2005). Further, many employers refer to motivational or attitudinal deficiencies in their existing or potential employees as skill shortages, suggesting that social skills are an important element in addition to technical proficiency (Moriarty et al. 2012, for Ireland; Oliver and Turton 1982, for the UK). These differences in how employers may interpret a skill shortage highlight the potential gains in understanding from looking in closer detail at how employers actually respond to self-reported shortages, and whether these result in measurable consequences for firms' performance - as we do in the current paper. 
Further ambiguities arise when considering how employers respond to skill shortages. Hiring standards may be adjusted according to the business cycle and the state of the labour market. When demand is buoyant, employers may be forced to take on workers who lack experience or other desirable attributes. When demand is depressed and labour abundant, employers may raise their expectations and look for qualities beyond the required technical capabilities (Richardson 2007). In tight (slack) labour markets, the incidence of under-(over-) education and under-(over-) skilling is therefore likely to increase, with implications for the likelihood of firms offering both internal and external training in response. Stevens (2007) shows for the UK that non-wage adjustments are preferred in tight labour markets where raising wages becomes more costly and less effective. Indeed, wages are generally found to be far from the most popular or effective means at the disposal of employers for adjusting to skill shortages (Fang 2009, for Canada; Haskel and Martin 1993a; Mason and Stevens 2003, for the UK). Manning (2003) argues that the lack of wage adjustments in response to skill shortages may reflect the ubiquity of labour market monopsony, even among smaller firms.

Training is an important alternative to raising wages in areas where skills can be learned quickly (Richardson 2007). However, the appeal of training may be reduced for employers by high rates of training non-completion, and problems with poaching by rival firms, especially where the training imparts general, as opposed to firm-specific, skills (Becker 1964; Mitchell and Quirk 2005). Other strategies for preventing or alleviating skill shortages include gaining a reputation for being a good employer through consultative employment relations (BackesGellner and Tuor 2010, for Germany).

There have been few studies of the impact of skill shortages on firm performance, largely due to a lack of suitable data. ${ }^{2}$ Haskel and Martin (1993b) argue that skill shortages lower output in at least two ways: first, by increasing hiring costs for skilled workers, causing them to be 
replaced by less-skilled workers; and, second, by increasing the bargaining power of skilled workers, allowing them to choose an easier pace of work for a given wage. Using a panel of UK industries, they find that an increase in skilled labour shortages reduces productivity growth significantly.

Bennett and McGuinness (2009) provide further evidence of the impacts of skill shortages for a small sample $(\mathrm{N}=242)$ of Irish IT and engineering firms. The authors use two measures of shortage - 'hard-to-fill' vacancies, and the number of unfilled vacancies in the previous 12 months - and find that both measures are associated with substantially lower levels of firm productivity (measured by output per worker). The same authors also consider the responses of firms to skill shortages, and show that the most common responses are to raise wages (for 63 per cent of affected firms), to train existing staff (58 per cent), and to change internal management structures or practices (33 per cent). Bellman and Hubler (2014) also find that training is important in reducing the number of unfilled vacancies in their survey of German establishments, but these studies are not limited to SMEs.

In this paper, we develop the existing literature in several ways. Notably, we demonstrate that: (i) the responses of firms to skill shortages are influenced by the type of shortage they confront, and (ii) the types of shortages and the responses they elicit influence the subsequent sales performance of affected firms. Our analysis is undertaken for a large sample of SMEs, with broad industry coverage, and using empirical methods that offer new insights into the economic and policy significance of the skill shortage phenomenon.

\section{Data and methods}

\section{Data source}

We analyse data from the Business Longitudinal Database (BLD), an Australian Bureau of Statistics (ABS) panel dataset covering small and medium-sized enterprises (SMEs). ${ }^{3}$ The 
scope of the BLD is restricted to businesses that are actively trading, meaning those with an Australian Business Number (ABN) that are remitting the Goods and Services Tax (GST). Businesses with up to 200 employees are included in the sample, and government authorities, financial entities, and not-for-profit organisations are excluded.

Each panel of the BLD is a stratified sample that represents the (in-scope) Australian SME population at the time of its initiation, which for the data used in this paper was the $30^{\text {th }}$ of June 2005. The main sample stratification variables in the BLD are industry and initial employment size. The sample is constructed so that at least 30 firms per stratum remain 'live' (actively trading) after five years, when data collection concludes for that panel. ${ }^{4}$

The BLD data come from two main sources. The first is the Business Characteristics Survey (BCS), an annual mail-out survey conducted by the ABS. This has a core set of questions that is repeated each year. To reduce respondent burden, much of this information is categorical. Response rates for the BCS were 95 per cent or above for each year of data that we analyse. The second data source is administrative records of the Australian Taxation Office (ATO), which provide information on total sales and total wages and salaries for each firm.

We analyse data on 2263 firms followed over three consecutive financial years (2004-05 to 2006-07). Out of the 2263 firms, 438 reported a skill shortage in 2004-05 and it is these firms that are used to establish the impact of skill shortages on firm performance. These original sample sizes are reduced by some item non-response and attrition. Table 1 shows the final number of useable observations for each variable.

$<$ Table 1 here $>$ 


\section{The measurement of skill shortages}

A skill shortage was defined in the 2004-05 BCS data as an 'insufficient supply of appropriately qualified workers available or willing to work under existing market conditions’. A ‘yes/no’ response was elicited to the question:

Did this business have skill shortages during the year to 30 June 2005?

This question provides no information about the intensity of a skill shortage, such as the proportion of vacancies that are hard to fill or the average time taken to fill them. However, we do have two firm-specific indicators of intensity in terms of (i) the number of separately identified causes of shortages and (ii) the number of years over the period considered during which these shortages were present. Watson, Johnson and Webb (2006), for example, emphasise the importance of accounting for severity of skill shortages, while acknowledging that this is an important gap in their analysis. We improve on the analysis of that paper in two ways, first by having repeat observations of the same firms over time and second, by having firm performance data that are not derived from subjective survey responses, but rather from an objective and highly reliable outside source (the ATO). Businesses that reported a skill shortage by answering 'yes' to the above question were asked two further questions about its causes and their responses. Both questions offered multiple response options and permitted any combination of them to be chosen. Six 'cause' options and seven 'response' options were provided in the questionnaire. Respondents could also choose 'other (please specify)' in both cases.

For the causes, businesses with skill shortages were asked:

Were this business's skill shortages due to any of the following factors?

And for the responses, they were asked: 
How did this business address skill shortages during the year ended 30 June $2005 ?$

Descriptive statistics for the data we use can be found in Table 1. Both measures of skill shortage causes and responses have been comprehensively answered, with only 8 per cent of firms having answered the generic 'other' category. This implies that there were few types of causes and responses that were not explicitly covered by the definitions provided by the data.

An important issue for our analysis is how long skill shortages endure. Whilst the original question on skill shortages was not asked after 2004-05, the following question was asked:

During [the year] did any factors significantly hamper this business in: (a) the development or introduction of new or significantly improved goods, services, processes or methods; or (b) other business activities or performance?

One possible response to this question was: 'A lack of skilled persons within the business.' We use an affirmative answer to this question as a proxy for the presence of potential longlasting skill shortage effects, and identify the respondents who agreed with it. We estimate the difference in the probability that a business is hampered by a lack of skilled persons after one year (in 2005-06), and after two years (2006-07), depending on its situation in 2004-05. Our hypothesis is that if shortages are long-lasting, this probability should be higher (on a ceteris paribus basis) for firms that reported skill shortages in Wave 1.

Our analysis of the consequences of skill shortages on firm performance focuses on the change in total sales over one and two years. We use the ATO administrative data included in the BLD. Australian firms report their total sales regularly to the ATO to determine their GST liability. We calculate one-year and two-year percentage changes from the baseline of sales in 2004-05. 
Our multivariate estimations control for a range of firm characteristics. ${ }^{5}$ We include industry dummy variables, both because of their inherent interest, and to adjust for the design features (i.e., stratification) of the BLD sample, noted earlier. For the analyses that compare only those firms with skill shortages, we reduce the full set of industry dummies to a three-sector division (primary, secondary, tertiary) to reduce the chances of encountering too small cell sizes. We also control for the legal status of the firm (registered company is the reference group); for trading in multiple locations; for employment size in headcounts (reference: fewer than five employees); for the age of the firm (reference: 10 or more years); for whether only one person is responsible for major business decisions; for the number of major competitors (reference: three or more); and for online presence. We also include a continuous measure of the firm's wage bill in 2004-05, to test if high-wage firms are less prone to skill shortages (as reported by Green et al. 1998). This relationship may exist because high-wage firms are able to attract more suitably-qualified applicants and (or) reduce employee turnover. The wages data come from the ATO. ${ }^{6}$

\section{Descriptive statistics}

Table 1 presented above shows weighted mean statistics for the two samples used in our estimations: first for all firms in the sample; and second only for those firms that reported they had skill shortages in 2004-05. The first point to note is that only one in ten firms reported a skill shortage in 2004-05. Of these firms, nearly half (46 per cent) reported that the shortage had a single cause, another third (33 per cent) reported two causes, and the remaining 20 per cent reported three or more causes. We describe skill shortages as 'simple' if they have one cause and 'complex' if they have two or more causes. Examining the effects of these different types of shortages is a distinguishing feature of our analysis. 
The specific causes of skill shortages, and firms' responses to them, are also listed in Table 1. For the causes, the frequencies range from 59 per cent (for specialised knowledge required) to 13 per cent (for geographic location). For the responses, work intensification (increasing the working hours of current employees) is by far the most common action taken (49 per cent). Surprisingly, external training is the least common response (7 per cent), perhaps due to employers' concerns about skilled labour poaching, as noted earlier. This is in line with Watson, Johnson and Webb (2006), who report in their UK sub-regional analysis that there was no evidence that firms react to skill shortages by increasing training.

\section{Estimation methods}

We use several estimation methods to study the causes of, responses to, and effects of skill shortages: (i) ordered probit regression, to determine which types of firms are more likely to face complex shortages; (ii) binary probit regression, to examine the responses to shortages, and whether shortages are long-lasting; and (iii) ordinary least squares regression, to explore how shortages relate to sales performance. ${ }^{7}$ The full sample is used to compare outcomes for firms with and without skill shortages (e.g., to examine the performance effects). The subset of skill-shortage firms is used where the outcome variables are not observed in the absence of skill shortages (e.g., to examine the responses).

Given that the BLD data on skill shortages were all collected in Wave 1 (2004-05), we cannot answer causal questions about why skill shortages appear, or which causes trigger which responses. For these variables, we can only estimate associations. We have stronger causal evidence, however, about the consequences of skill shortages. This is because the data were collected after the skill shortages were first reported and, in the case of sales, were also collected independently of the BCS. 


\section{Complexity in the causes of skill shortages}

Which firms encounter skill shortages? We provide answers to this question by using the number of underlying causes reported by each firm to construct a measure of skill shortage complexity. We then use this measure to estimate the firm attributes that are associated not only with the presence/absence of shortages, but also with the degree of complexity present in their shortage. This approach has theoretical and empirical appeal because of the features of our dataset and the limitations of the available alternatives. ${ }^{8}$

Our complexity construct is only useful, however, if the distinction between 'simple' and 'complex' shortages is statistically supported by the data. To test this, we estimate an ordered probit model, where the dependent variable is the number of causes reported by each firm (including zero) and the independent variables are a vector of other relevant firm attributes. The first two columns of Table 2 show the results. The three cut-points at the base of the Table correspond to the thresholds between zero/one, one/two, and two/three or more reported causes of skill shortages. These are all highly statistically significant, suggesting that the distinction between simple and complex skill shortages is empirically justified and important to recognise in our analysis.

$<$ Table 2 here $>$

The other columns of Table 2 show marginal effects and significance levels for each firm attribute, with respect to the probability of skill shortages with one, two, and three or more causes. Most of the marginal effects can be interpreted as percentage changes relative to the reference group for that variable. For instance, the 0.053 coefficient for Construction in the 'One cause' results implies that Construction firms are about 5.3 per cent more likely than comparable Manufacturing firms (the reference industry) to encounter simple skill shortages. 
Table 2 shows pronounced industry differences, but not all of them are statistically significant. On average, skill shortages occur more frequently in four industries: Agriculture; Construction; Hospitality; and Personal Services. Construction and Personal Services firms appear particularly susceptible to highly-complex skill shortages (three or more causes), while Hospitality firms are only more likely to face simple skill shortages. The industries that are most prone to complex skill shortages have relatively little in common. Agriculture, Construction and Personal Services firms have very different product and labour markets and, presumably, quite distinctive skill requirements. This diversity suggests that skill shortages are unlikely to be resolved by uniform remedies imposed across different industries by firms or governments. It suggests that industry-specific policy will be more appropriate.

Employment size is an important determinant of skill shortages in Table 2, with larger firms having both a higher probability of any type of shortage and a higher probability of skill shortages that are complex. These patterns could be explained by larger firms having more advanced production processes or higher absolute turnover, but one must remember that the maximum firm size in the data is 200 employees. On the other hand, the differences may be simply an effect of firm 'scale', since the BLD does not allow us to determine the incidence of skill shortages per employee in each firm. One way to counter this data limitation is to introduce other information about firm scale to the model. We include each firm's total wage bill in 2004-05. Contrary to expectations, we find a positive association between this variable and the probability of each type of skill shortage, although the marginal effects are small and only weakly significant. We cannot measure compensation per employee in each firm, because the BLD employment variable is only available in broad categories that cannot be further divided. Thus, the wage effects in Table 2 will capture differences in both firm scale and firm compensation policies, which may explain the unexpected positive association with skill shortages that we find. 
The remaining determinant of the probability of skill shortages is a firm's product market environment ('market structure'). Monopolistic firms (no competitors) are 4-5 per cent less likely to encounter skill shortages than comparable firms with three or more competitors (the reference category). There is no difference in the probability of skill shortages between firms with one or two, versus three or more, competitors. Thus, the presence of any product market competition is relevant for skill shortages, rather than the number of competitors.

Market structure may influence skill shortages in many ways, including via the depressing product-price effect of competition, which can have a depressing (derived) effect on wages. Lower wages may reduce the number of people willing to work for a firm, which could lead to perceived skill shortages. Similarly, competitive markets may also suffer from more labour poaching, which can exacerbate skill shortages in the short-run, as workers exit, and in the longer-run, as employers become less willing to support general training. Our results suggest that interventions designed to prevent or curb the spread of skill shortages should focus not only on the most susceptible industries, but also on more competitive sections of those industries, where firms are vying for the same limited pool of skilled workers, but may be reluctant to invest in general training.

The remaining firm attributes in Table 2 are not significantly associated with skill shortage occurrence or severity. We had expected that firms that have been operating for longer, and that are promoting themselves online, might increase their visibility to potential recruits (or lower their search costs) enough to reduce the probability of skill shortages, but we find no evidence for these propositions. We also expected that firms with a single decision-maker might have problems with management style or work organisation that would lead to skill shortages, but this does not appear to be supported by our results. The main determinants of 
skill shortages in our analysis are industry, firm size, and market structure. The first two of these were also found to be important by Watson, Johnson and Webb (2006) for the UK.

\section{Adjusting to skill shortages}

Firms facing different types of skill shortages may take different actions to resolve them. Raising working hours for current employees may alleviate a shortage arising from product demand uncertainty or a slow recruitment process, but may do little if the cause is a need for specialised training. Understanding the circumstances in which each response is (and is not) likely to be taken by different firms is thus essential for designing effective remedies to skill shortages.

To study these associations, we use binary probit regressions to estimate the change in the probability of each response, after controlling for the key firm attributes that were associated with skill shortage incidence and complexity in Table 2. Our main results, shown in Table 3, control for complexity in the causes of skill shortages. We also provide additional results, in Appendix Table 1, which control separately for each of the individual skill-shortage causes. ${ }^{9}$

<Table 3 here; Appendix Table 1 to appear as supplementary material $>$

The coefficients on the two complexity variables in Table 3 suggest that most responses to skill shortages are sensitive to the presence of multiple causes. Notably, however, the threshold for this response sensitivity varies: for some responses, it is between one and two causes; for others, it is between two and three or more causes.

To illustrate this important result, consider in Table 3 column "Existing workforce longer hours”, which represents the most common response to skill shortages. This longer hours response is 12.5 per cent more likely to be taken when two causes of skill shortages are present than when one cause is present, and a further 6.7 per cent more likely when three or 
more causes are present (a total of 19.2 per cent). A similar pattern is seen in column "Wages or conditions increased”. Note that the crucial margin for both of these responses is between one and two causes. They are used when a firm moves from having a simple (single cause) shortage to a more complex (dual cause) shortage. Longer hours and higher wages/conditions can thus be likened to a 'first line of defence' against skill shortages. Their common trait is greater use of existing workers inducing longer hours and possibly higher effort levels, whilst allowing firms to retain managerial control, thereby reducing or avoiding the costs and risks of hiring new staff or outsourcing work.

Now consider the responses in which firms relinquish some managerial control. Column "Subcontracted or outsourced work" shows that the likelihood of outsourcing increases sharply (from 10.6 to 26.8 per cent) when three or more causes of skill shortage are present. Similarly, column "Employed on short-term contracts" shows that the likelihood of using short-term employment contracts doubles (from 6.1 to 12.9 per cent), and becomes statistically significant, if three or more causes are present. Finally, column "Reduce outputs or production" shows that the likelihood of a firm reducing output, arguably the most serious response, only reaches statistical significance in the presence of three or more causes. Most firms do not seem to use these responses as initial adjustments to skill shortages, which makes intuitive sense, since each of them entails additional uncertainty: the need to monitor quality more closely when outsourcing or hiring temporary workers; the risk that productivity and market visibility may be permanently damaged by reducing output.

The interpretation of these results is clear and important. Complexity in the causes of skill shortages matters for how firms respond. The pattern suggested by our results is that firms initially look to their 'core’ workforce, by utilising more intensively their existing employees. As shortages become more complex, firms use their core workers still more, and may raise 
their wages, but there are limits to these responses. Firms then turn to other externalisation strategies that involve higher costs and uncertainty when more complex shortages cannot be handled adequately by their internal capacities to cope. Finally, if all else fails in the efforts to remove highly complex skill shortages, firms may cut output.

Appendix Table 1 provides complementary evidence of how the specific skill shortage causes are related to the responses. The results are generally in line with expectations. For instance, firms with long-term demand fluctuations and slow recruitment processes are more likely to call on their current workers to assist through longer hours. Short-term contracts are another option used when recruitment is too slow. Outsourcing is used to obtain specialist knowledge, to reduce labour costs, and to smooth product-demand fluctuations. Internal training is more frequently offered by firms needing specific knowledge that the external training system does not provide (hence their skill shortage). While most of the associations reported in Appendix Table 1 are positive, we note that the probability of internal training is significantly lower for firms that regard high labour costs as a cause of their skill shortage. In a high-wage market, firms are more likely to expect recruits to arrive fully-trained and job-ready, as they fear that trainees will otherwise be poached and leave the firm with no return on its training outlay.

Table 3 and Appendix Table 1 also show a number of interesting associations between the responses to skill shortages and other firm attributes. First, larger firms are more likely to offer internal training. They may have more specialised production requirements, or may find common skill deficiencies in their recruits, that can be corrected efficiently through such training. Second, there is a positive association between a firm's wage bill and its probability of increasing wages or working conditions in response to a skill shortage. This may be because firms operating in tight labour markets must raise their wage offers to attract or retain workers. Unfortunately, the BLD has no information on firms' wages before the initial 
report of a skill shortage. Third, we find no evidence that responses to skill shortages are influenced independently by market structure. Hence, while the number of competitors is important in whether skill shortages occur (Table 2), it is not important (ceteris paribus) in how firms respond once they are present. If most firms respond to skill shortages internally, without concern for their competitors' strategies, then it is possible that more effective collective responses are not being adopted or even contemplated. Governments may have a useful role to play in encouraging and coordinating such collective responses, where skill shortages are afflicting many firms in the same industry or region, and especially where these shortages are more complex in nature.

\section{Consequences of skill shortages}

We consider the short-term consequences of skill shortages, using two separate measures of firm performance. ${ }^{10}$ Our 'subjective' measure is whether the firm's performance was seen as being significantly hampered by a lack of skilled persons one or two years after the skill shortage was first reported, and is shown in Table 4. We might regard skill shortages as benign if, shortly after they appear, firms no longer see any serious skill-based impediment to their performance. The reverse would be true if skill deficiencies were often longer-lasting. Our 'objective' measure of performance is the change in each firm's total sales, relative to 2004-05, and is shown in Table 5. The sales data are reported contemporaneously to the ATO, with penalties for misreporting, so they are of high quality and unaffected by recall error. $^{11}$

\section{Longer-lasting skills problems}

Table 4 shows the results from our estimations of the subjective performance effects by reporting the position of the firms one year later and two years later. There is clear evidence that skill shortages have different consequences, depending on the degree of complexity in 
their underlying causes. Firms with a simple (single-cause) shortage were 22.8 per cent more likely to report a lack of skilled persons one year later (in 2005-06), and 9.4 per cent more likely to do so two years later (in 2006-07), than comparable firms without any shortage in 2004-05. Note the substantial (13.4 percentage point) reduction in this probability between the two years. The high statistical significance of this difference suggests that simple skill shortages are less likely to have long-lasting effects. Two years after encountering such a shortage, the average firm has managed to reduce significantly its probability of still being hampered in its performance by a lack of skills.

\section{$<$ Table 4 here $>$}

Now contrast the experiences of firms that had more complex skill shortages in 2004-05. For firms with dual-cause shortages, there is a similar 'taper' in the probability of being hampered by subsequent skill deficiencies, but the 4.8 percentage point reduction, from 26.5 per cent (after one year) to 21.7 per cent (after two years), is not statistically significant in its own right. Firms whose skill shortages had three or more causes in 2004-05 face a persistently higher probability of subsequent skill deficiencies although, again, the change itself (from 36.3 to 39.6 per cent) is not significant. Taken together, these results suggest that simple and more complex skill shortages affect firms quite differently, with greater complexity being associated with longer-lasting problems.

\section{Short-term changes in sales}

Our final set of results examines the relationship between skill shortages and a key measure of firms' objective performance: growth in sales. We have tax office data on the sales of each firm in three consecutive years, from which we construct variables for the percentage change in sales over one year (2004-05 to 2005-06) and two years (2004-05 to 2006-07). Using OLS, 
we estimate two separate linear regressions of the change in sales on skill shortages and other key firm attributes.

$<$ Table 5 here $>$

To overcome potential problems with reverse causality, we distinguish between several types of skill shortages, according to their onset timing and duration. For instance, we compare the (ceteris paribus) sales change for firms with no skill shortage in any of the three observation years to firms with shortages in one year, two years, and all three years. We are particularly interested in the outcomes for firms that did not have a shortage in 2004-05 (the first year that we observe them in the BLD) and then moved into shortage in either of the subsequent two years. These firms provide our clearest evidence of the causal relationship between skill shortages and the change in sales.

Recall from earlier discussion that the BLD measures of skill shortage causes and responses were not repeated after Year 1 (2004-05). This data limitation reduces the range of possible analyses. For instance, we cannot compare sales outcomes for firms that enter, exit, or remain in a complex skill-shortage state, because we only have the necessary information for Year 1. The results in Table 5 are thus based on a simplified model, which uses only the presence/absence of skills-related problems to construct the control variables of interest. We treat the 'skill shortage' variable collected in Year 1 as being equivalent to the 'hampered by a lack of skilled persons' variable collected in Years 2 and 3. The two skill variables are not perfectly interchangeable, but there is a sufficiently strong correlation between them, as established by our results in Table 4, to justify using them in this way for the sales analysis. To simplify the results, we refer to both conditions as 'shortage' in Table 5.

Our a priori expectation was that skill shortages would impose costs on affected firms that would significantly reduce their sales performance relative to comparable, unaffected firms. 
Such an effect might be present, for instance, because skill-shortage firms are less efficient in production and hiring, making them less competitive, and less likely to improve their market position and, hence, their sales. Alternatively, firms might be less able to respond to natural workforce attrition when skill shortages are present. When workers move or retire, their firms might find it difficult to recruit a suitable replacement worker, especially if (as we showed in earlier results) filling the vacancy requires specialist knowledge or an increase in starting pay. These possibilities led us to expect a negative association between skill shortages and sales.

Instead, as seen in Table 5, we find no evidence of such an effect in either estimation of the change in sales. The coefficients on most of the skill shortage variables are not significantly different from zero, meaning that the firms in these groups perform no differently on sales from those in the (no-shortage) reference group. Further, whenever the shortage coefficients are statistically significant, their sign is positive, implying superior sales performance to the reference group. In both estimations, the firms with the best sales performance are those that reported ongoing skill shortages. These firms increased their sales relative to the base group by 16 per cent on average over one year, and by 23 per cent on average over two years. These results go against our expectations. Their novelty is underlined further by the result for firms that were free of any shortage in Wave 1 and that then encountered a shortage in Wave 2. If the hypothesis of an adverse sales impact of shortage were supported by the data, the sign on this particular coefficient should be negative. Instead it is positive and significant; suggesting that these firms also experienced a lift in their relative sales even as they encountered a skill shortage. Any positive effect appears to be short-lived, however; in the estimation of the sales change over two years, there is no significant difference for this group of firms.

Our results are open to different interpretations. One possibility is that firms do not find the notion of a skill shortage to be particularly troublesome. In this case, some may report facing 
a skill shortage even though there is no fundamental consequence for the firm's performance. We are inclined to discount this possibility, however, since the variable we have used for the shortage measure in Years 2 and 3 (but not in Year 1) explicitly indicates a view that the firm is being 'significantly hampered' by a lack of available skills. Another possibility is that the firms with persistent skill shortages are well adapted to dealing with them. Although the firm could be performing better if it achieved the optimal skills mix, the performance (in terms of our objective assessment) is still superior to that of other similar firms. If this interpretation is correct, then the notion that the firm is being 'significantly hampered' may be a recognition that the firm is not attaining its full potential, rather than an admission that the firm is failing. Finally, there may be other factors in play that dilute or override any detectable adverse effect of skill shortages on sales. Other unobserved attributes of the firm, or its wider product and labour markets, may also be driving up the relative sales performance of skill-shortage firms.

\section{Conclusion}

We have introduced the notion of 'complexity' as a basis for analysing the differences in skill shortage types and in SMEs' success in adjusting to them. We have demonstrated empirically the importance of this complexity construct for understanding how skill shortages manifest themselves and how they impact on a range of firm behaviours and outcomes. We echo the sentiments of Bosworth (1993: 242), who observed that:

Where skill shortages are widespread, a large number of employers will report recruitment problems... Where the shortage problem is not spread evenly across firms however, a small number of employers may have relatively severe problems. The causes of these two types of shortage may be quite different and, hence, the nature of government responses and the ways in which policies are targeted may also need to be different.

Our study provides empirical evidence in support of the theoretical and practical significance of this observation. Most firms address skill shortages through better utilisation of their 'core' 
workforce (e.g. longer hours and better pay), while some use 'peripheral' strategies (e.g. outsourcing and temporary employment). A small, but still significant, proportion of firms reduce output. The interaction between complexity in the causes of skill shortages and the nature of firms' responses is both empirically and practically important. We have shown that some responses are used where there are simple causes of skill shortages, while others are activated only in the presence of multiple causes. We have also shown that simple skill shortages are more likely to resolve quickly than complex ones.

Our finding that skill shortages are not negatively related to a firm's subsequent sales performance remains an empirical puzzle. We are not certain that it reflects the absence of an underlying relationship, given the other evidence from our analysis that complex skill shortages are longer-lasting and associated with an increased likelihood of output reductions. Nor are we certain whether the 'reduced output' response means that firms have reduced their output in absolute terms, or rather that they believe potentially higher output was foregone because of the skill shortage. There is some tension in our results between, on the one hand, the finding that complex skill shortages raise the probability of reducing outputs, and, on the other hand, the lack of any evidence that skill shortages reduce sales performance. Resolving this tension would be a useful direction for further research.

At a practical level, our results suggest that external intervention to alleviate skill shortages should emphasise complex cases, since simple cases appear more likely to dissipate over time. Governments should seek to identify and monitor the prevalence of skill shortages with multiple causes in standard employer surveys. In the short-run, employers can be expected to utilise their existing workforces more intensively and this will buy time. In more complex cases, increasing hours can serve as an early warning system. The single most important 
cause of skill shortages, however, is a requirement for specialised knowledge. To the extent that this entails specific skills, employer involvement in dealing with the problem is essential.

\section{References}

ABS (Australian Bureau of Statistics) (2009) Technical Manual, Business Longitudinal Database, Expanded Confidentialised Unit Record File, Australia, 2004-05, 2005-06 and 2006-07, ABS catalogue no. 8168.0.55.002, Canberra.

ABS (Australian Bureau of Statistics) (2011) Labour Force, Australia, Time Series Spreadsheets, Table 01: Labour Force Status by Sex - Trend, ABS catalogue no. 6202.0, Canberra.

ABS (Australian Bureau of Statistics) (2013) Counts of Australian Businesses, Including Entries and Exits, June 2008 to June 2012, ABS catalogue no. 8165.0, Canberra.

Backes-Gellner, U. and Tuor, S.N. (2010) 'Avoiding labor shortages by employer signaling - On the importance of good work climate and labor relations’, Industrial and Labor Relations Review, 63(2): 271-285.

Becker G.S. (1964) Human Capital; A Theoretical and Empirical Analysis, with Special Reference to Education, University of Chicago Press, Chicago.

Bellman, L. and Hubler, O. (2014) ‘Skill shortages in German establishments’, IZA Discussion Paper no. 8290, Institute for the Study of Labor, Bonn.

Bennett, J. and McGuinness, S. (2009) 'Assessing the impact of skill shortages on the productivity performance of high-tech firms in Northern Ireland', Applied Economics, 41(6): 727-737.

Bosworth D. (1993) 'Skill shortages in Britain', Scottish Journal of Political Economy, 40(3): 241271.

Cappelli P. (2005) ‘Will there really be a labor shortage?’ Human Resource Management, 44(2): 143149.

Cappelli, P. (2014) 'Skill gaps, skill shortages and skill mismatches: Evidence for the US', NBER Working Paper no. 20382, National Bureau of Economic Research, Cambridge, MA.

Coelli, M. and Wilkins, R. (2008) 'Are skill shortages a constraint on increasing employment in Australia?' Australian Economic Review, 41(3): 310-322.

Cohen, M.S. and Zaidi, M.A. (2002) Global Skill Shortages, Edward Elgar, Cheltenham, UK.

Fang, T. (2009) 'Workplace responses to vacancies and skill shortages in Canada', International Journal of Manpower, 30(4): 326-348.

Green, F., Machin, S. and Wilkinson, D. (1998) 'The meaning and determinants of skill shortages', Oxford Bulletin of Economics and Statistics, 60(2):165-187.

Haskel, J. and Martin, C. (1993a) 'The causes of skill shortages in Britain', Oxford Economic Papers, 45: 573-588. 
Haskel, J. and Martin, C. (1993b) 'Do skill shortages reduce productivity? Theory and evidence for the UK', Economic Journal, 103(417): 386-394.

Healy, J., Mavromaras, K. and Sloane, P.J. (2011) Skill Shortages: Prevalence, Causes, Remedies and Consequences for Australian Businesses, NCVER Monograph Series 09/12, National Centre for Vocational Education Research, Adelaide.

Junankar, P.N. (2009) ‘Was there a skill shortage in Australia?’ IZA Discussion Paper no.4651, Institute for the Study of Labor, Bonn.

Manning, A. (2003) Monopsony in Motion; Imperfect Competition in Labor Markets, Princeton University Press, New Jersey.

Mason, G. and Stevens, P. (2003) 'The determinants of hard-to-fill vacancies and skill-shortage vacancies in key occupational groups', in G. Mason and R. Wilson (ed.) Employers Skill Survey: New Analyses and Lessons Learned, pp.136-185, Department for Education and Skills, London.

Mitchell, W. and Quirk, V. (2005) ‘Skill shortages in Australia: Concepts and reality’, Centre of Full Employment and Equity Working Paper no.05-16, University of Newcastle.

Mok, P., Mason, G., Stevens, P. and Timmins, J. (2012) 'A good worker is hard to find: Skill shortages in New Zealand firms’, Ministry of Economic Development, Occasional Paper 12/05, New Zealand.

Moriarty, E., Wickham, J., Krings, T., Salamonska, J. and Bobek, A. (2012) ““Taking on almost everyone?” Migrant and employer recruitment strategies in a booming labour market', The International Journal of Human Resource Management, 23(9): 1871-1887.

Oliver, J.M. and Turton, J.R. (1982) 'Is there a shortage of skilled labour?’ British Journal of Industrial Relations, 20(2): 195-200.

Richardson, S. (2007) 'What is a skill shortage?' National Centre for Vocational Education Research, Adelaide.

Shah, C. and Burke, G. (2005) 'Skill shortages: Concepts, measurement, and policy responses', Australian Bulletin of Labour, 31(1): 44-71.

Stevens, P.A. (2007) 'Skill shortages and firms’ employment behaviour', Labour Economics, 14(2): 231-250.

Watson D., Johnson, S. and Webb, R. (2006) 'Employer perceptions of skills deficiencies in the UK labour market: A subregional analysis’, Environment and Planning A, 38: 1753-1771.

Winship, C. and Radbill, L. (1994) 'Sampling weights and regression analysis', Sociological Methods \& Research, 23(2): 230-257. 
Table 1: Weighted Mean Statistics and Unweighted Sample Sizes for Estimation Variables

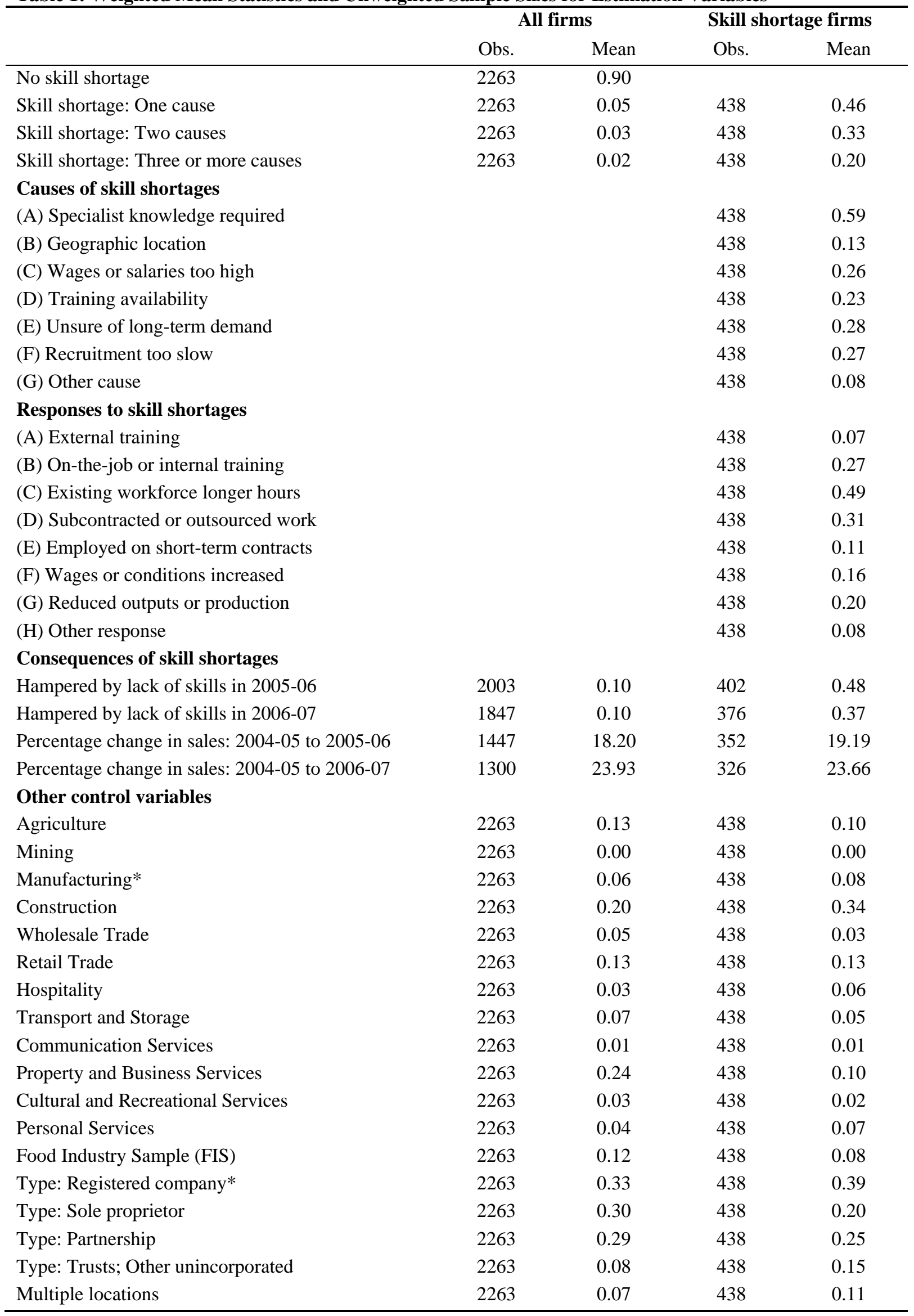




\begin{tabular}{lllll}
\hline Size: Fewer than 5 employees* & 2263 & 0.83 & 438 & 0.54 \\
Size: 5-19 employees & 2263 & 0.14 & 438 & 0.33 \\
Size: $20-199$ employees & 2263 & 0.03 & 438 & 0.12 \\
Age: Less than 5 years in operation & 2222 & 0.31 & 434 & 0.35 \\
Age: 5 to less than 10 years in operation & 2222 & 0.20 & 434 & 0.19 \\
Age: 10 or more years in operation* & 2222 & 0.49 & 434 & 0.46 \\
Single decision-maker & 2263 & 0.63 & 438 & 0.68 \\
No competitors & 1991 & 0.36 & 413 & 0.12 \\
One or two competitors & 1991 & 0.12 & 413 & 0.12 \\
Three or more competitors* & 1991 & 0.51 & 413 & 0.76 \\
Web presence & 2263 & 0.20 & 438 & 0.34 \\
Log of wages in 2004-05 & 1872 & 3.36 & 416 & 4.38 \\
\hline
\end{tabular}

Notes: (1) Sampling weights used in calculations; (2) Asterisks show omitted (reference) categories in dummy variable sets. 
Table 2: Coefficients and Marginal Effects from Ordered Probit of the Number of Skill Shortage Causes

\begin{tabular}{|c|c|c|c|c|c|c|c|c|}
\hline & \multirow[b]{2}{*}{ Coeff. } & \multirow[b]{2}{*}{$\mathrm{P}>|\mathrm{z}|$} & \multicolumn{2}{|c|}{ One cause } & \multicolumn{2}{|c|}{ Two causes } & \multicolumn{2}{|c|}{ Three or more causes } \\
\hline & & & $\mathrm{dy} / \mathrm{dx}$ & $\mathrm{P}>|\mathrm{z}|$ & $\mathrm{dy} / \mathrm{dx}$ & $\mathrm{P}>|\mathrm{z}|$ & $\mathrm{dy} / \mathrm{dx}$ & $\mathrm{P}>|\mathrm{z}|$ \\
\hline \multicolumn{9}{|l|}{ Base: Manufacturing } \\
\hline Agriculture & $0.502 * * *$ & 0.000 & $0.046^{* * *}$ & 0.000 & $0.051^{* * *}$ & 0.000 & $0.062 * * *$ & 0.002 \\
\hline Mining & 0.261 & 0.202 & 0.025 & 0.186 & 0.026 & 0.230 & 0.031 & 0.285 \\
\hline Construction & $0.612^{* * *}$ & 0.000 & $0.053^{* * *}$ & 0.000 & $0.065^{* * *}$ & 0.000 & $0.091^{* * *}$ & 0.007 \\
\hline Wholesale Trade & -0.174 & 0.254 & -0.017 & 0.249 & -0.015 & 0.231 & -0.015 & 0.194 \\
\hline Retail Trade & 0.111 & 0.529 & 0.011 & 0.527 & 0.011 & 0.542 & 0.012 & 0.560 \\
\hline Hospitality & $0.329 * *$ & 0.046 & $0.031^{* *}$ & 0.037 & $0.034^{*}$ & 0.058 & 0.040 & 0.108 \\
\hline Transport and Storage & 0.287 & 0.121 & 0.027 & 0.106 & 0.029 & 0.141 & 0.034 & 0.204 \\
\hline Communication Services & 0.264 & 0.215 & 0.025 & 0.196 & 0.027 & 0.242 & 0.031 & 0.303 \\
\hline Property and Business Services & 0.001 & 0.996 & 0.000 & 0.996 & 0.000 & 0.996 & 0.000 & 0.996 \\
\hline Cultural and Recreational Services & -0.179 & 0.384 & -0.017 & 0.378 & -0.016 & 0.352 & -0.015 & 0.313 \\
\hline Personal Services & $0.692 * * *$ & 0.000 & $0.058 * * *$ & 0.000 & $0.073 * * *$ & 0.000 & $0.107 * * *$ & 0.003 \\
\hline Food Industry Sample (FIS) & $0.198 *$ & 0.073 & $0.019 *$ & 0.073 & $0.019 *$ & 0.078 & $0.020^{*}$ & 0.098 \\
\hline \multicolumn{9}{|l|}{ Base: Registered company } \\
\hline Sole proprietor & 0.032 & 0.823 & 0.003 & 0.823 & 0.003 & 0.825 & 0.003 & 0.827 \\
\hline Partnership & -0.047 & 0.688 & -0.005 & 0.688 & -0.004 & 0.684 & -0.004 & 0.681 \\
\hline Trusts; Other unincorporated & $-0.141 *$ & 0.099 & $-0.014^{*}$ & 0.096 & $-0.013^{*}$ & 0.087 & $-0.013^{*}$ & 0.085 \\
\hline Multiple locations & 0.106 & 0.239 & 0.010 & 0.239 & 0.010 & 0.248 & 0.011 & 0.270 \\
\hline \multicolumn{9}{|l|}{ Base: Fewer than 5 employees } \\
\hline 5-19 employees & $0.490 * * *$ & 0.000 & $0.046 * * *$ & 0.000 & $0.048 * * *$ & 0.000 & $0.054^{* * *}$ & 0.000 \\
\hline 20-199 employees & $0.624 * * *$ & 0.000 & $0.056 * * *$ & 0.000 & $0.063^{* * *}$ & 0.000 & $0.079 * * *$ & 0.000 \\
\hline \multicolumn{9}{|l|}{ Base: 10 or more years in operation } \\
\hline Less than 5 years in operation & 0.049 & 0.607 & 0.005 & 0.607 & 0.005 & 0.611 & 0.005 & 0.616 \\
\hline 5 to less than 10 years in operation & -0.061 & 0.510 & -0.006 & 0.510 & -0.006 & 0.504 & -0.006 & 0.497 \\
\hline Single decision-maker & 0.101 & 0.165 & 0.010 & 0.167 & 0.009 & 0.166 & 0.010 & 0.160 \\
\hline \multicolumn{9}{|l|}{ Base: Three or more competitors } \\
\hline No competitors & $-0.537 * * *$ & 0.000 & $-0.049 * * *$ & 0.000 & $-0.043 * * *$ & 0.000 & $-0.040 * * *$ & 0.000 \\
\hline One or two competitors & -0.088 & 0.389 & -0.008 & 0.388 & -0.008 & 0.378 & -0.008 & 0.361 \\
\hline Web presence & 0.029 & 0.712 & 0.003 & 0.713 & 0.003 & 0.713 & 0.003 & 0.713 \\
\hline Log of wages in 2004-05 & $0.051 *$ & 0.054 & $0.005^{*}$ & 0.055 & $0.005^{*}$ & 0.059 & $0.005^{*}$ & 0.053 \\
\hline Cut1 & 1.603 & & & & & & & \\
\hline Cut2 & 2.005 & & & & & & & \\
\hline Cut3 & 2.474 & & & & & & & \\
\hline N Observations & 1644 & & & & & & & \\
\hline Pseudo R-squared & 0.071 & & & & & & & \\
\hline
\end{tabular}

Notes: ${ }^{*} p<0.10,{ }^{* *} p<0.05, * * * p<0.01$ 
Table 3: Probit Estimations of the Responses to Skill Shortages

\begin{tabular}{|c|c|c|c|c|c|c|c|c|c|c|c|c|}
\hline & \multicolumn{2}{|c|}{$\begin{array}{c}\text { (C) Existing } \\
\text { workforce longer } \\
\text { hours }\end{array}$} & \multicolumn{2}{|c|}{$\begin{array}{l}\text { (D) Subcontracted } \\
\text { or outsourced work }\end{array}$} & \multicolumn{2}{|c|}{$\begin{array}{l}\text { (B) On-the-job or } \\
\text { internal training }\end{array}$} & \multicolumn{2}{|c|}{$\begin{array}{l}\text { (G) Reduce outputs } \\
\text { or production }\end{array}$} & \multicolumn{2}{|c|}{$\begin{array}{l}\text { (F) Wages or } \\
\text { conditions } \\
\text { increased }\end{array}$} & \multicolumn{2}{|c|}{$\begin{array}{l}\text { (E) Employed on } \\
\text { short-term } \\
\text { contracts }\end{array}$} \\
\hline & $\mathrm{dF} / \mathrm{dx}$ & $\mathrm{P}>|\mathrm{z}|$ & $\mathrm{dF} / \mathrm{dx}$ & $\mathrm{P}>|\mathrm{z}|$ & $\mathrm{dF} / \mathrm{dx}$ & $\mathrm{P}>|\mathrm{z}|$ & $\mathrm{dF} / \mathrm{dx}$ & $\mathrm{P}>|\mathrm{z}|$ & $\mathrm{dF} / \mathrm{dx}$ & $\mathrm{P}>|\mathrm{z}|$ & $\mathrm{dF} / \mathrm{dx}$ & $\mathrm{P}>|\mathrm{z}|$ \\
\hline \multicolumn{13}{|l|}{ Base: One cause } \\
\hline Two causes & $0.125^{* *}$ & 0.035 & $0.106^{*}$ & 0.058 & 0.073 & 0.225 & 0.060 & 0.268 & $0.162 * * *$ & 0.004 & 0.061 & 0.156 \\
\hline Three or more causes & $0.192 * * *$ & 0.003 & $0.268 * * *$ & 0.000 & $0.120^{*}$ & 0.065 & $0.254 * * *$ & 0.000 & $0.213^{* * *}$ & 0.000 & $0.129 * * *$ & 0.007 \\
\hline \multicolumn{13}{|l|}{ Base: Tertiary sector } \\
\hline Primary sector & 0.042 & 0.552 & $0.119 *$ & 0.065 & -0.073 & 0.309 & 0.057 & 0.351 & 0.056 & 0.382 & $0.143^{* * *}$ & 0.005 \\
\hline Secondary sector & $0.147 * *$ & 0.025 & $0.117^{*}$ & 0.059 & -0.055 & 0.386 & 0.028 & 0.628 & 0.004 & 0.944 & 0.047 & 0.323 \\
\hline Food Industry Sample (FIS) & -0.041 & 0.531 & $-0.152 * * *$ & 0.006 & 0.013 & 0.834 & 0.033 & 0.556 & $-0.094 *$ & 0.093 & -0.028 & 0.481 \\
\hline \multicolumn{13}{|l|}{ Base: 0-4 employees } \\
\hline 5-19 employees & $0.143^{*}$ & 0.074 & -0.082 & 0.231 & $0.191^{* *}$ & 0.022 & -0.084 & 0.196 & 0.099 & 0.178 & 0.052 & 0.287 \\
\hline 20-199 employees & 0.045 & 0.665 & -0.055 & 0.523 & $0.309 * * *$ & 0.004 & -0.026 & 0.764 & 0.029 & 0.756 & 0.053 & 0.392 \\
\hline \multicolumn{13}{|l|}{$\begin{array}{l}\text { Base: Three or more } \\
\text { competitors }\end{array}$} \\
\hline No competitors & -0.083 & 0.377 & -0.015 & 0.840 & -0.071 & 0.451 & 0.024 & 0.769 & -0.015 & 0.847 & 0.003 & 0.962 \\
\hline One or two competitors & -0.073 & 0.335 & 0.066 & 0.318 & 0.007 & 0.927 & -0.004 & 0.948 & -0.021 & 0.741 & 0.030 & 0.560 \\
\hline Log of wages in 2004-05 & 0.000 & 0.996 & 0.023 & 0.188 & -0.012 & 0.550 & -0.019 & 0.246 & $0.038 *$ & 0.060 & -0.009 & 0.454 \\
\hline Observed P & 0.551 & & 0.263 & & 0.411 & & 0.255 & & 0.270 & & 0.135 & \\
\hline Predicted P & 0.554 & & 0.246 & & 0.406 & & 0.241 & & 0.253 & & 0.121 & \\
\hline N Observations & 392 & & 392 & & 392 & & 392 & & 392 & & 392 & \\
\hline Pseudo R-squared & 0.040 & & 0.075 & & 0.040 & & 0.065 & & 0.070 & & 0.062 & \\
\hline
\end{tabular}

Notes: ${ }^{*} p<0.10,{ }^{* *} p<0.05,{ }^{* * *} p<0.01$ 
Table 4: Probit Estimations of Short-term Performance Effects of Skill Shortages

\begin{tabular}{|c|c|c|c|c|}
\hline & \multicolumn{2}{|c|}{$\begin{array}{c}\text { Hampered by lack of skills } \\
\text { one year later }\end{array}$} & \multicolumn{2}{|c|}{$\begin{array}{c}\text { Hampered by lack of skills } \\
\text { two years later }\end{array}$} \\
\hline & $\mathrm{dF} / \mathrm{dx}$ & $\mathrm{P}>|\mathrm{z}|$ & $\mathrm{dF} / \mathrm{dx}$ & $\mathrm{P}>|\mathrm{z}|$ \\
\hline \multicolumn{5}{|l|}{ Base: No skill shortage } \\
\hline One cause & $0.228 * * *$ & 0.000 & $0.094^{* *}$ & 0.010 \\
\hline Two causes & $0.265^{* * *}$ & 0.000 & $0.217 * * *$ & 0.000 \\
\hline Three or more causes & $0.363^{* * *}$ & 0.000 & $0.396 * * *$ & 0.000 \\
\hline \multicolumn{5}{|l|}{ Base: Manufacturing } \\
\hline Agriculture & -0.034 & 0.273 & $-0.088 * * *$ & 0.006 \\
\hline Mining & $-0.088 *$ & 0.093 & -0.023 & 0.698 \\
\hline Construction & -0.063 & 0.145 & 0.032 & 0.554 \\
\hline Wholesale Trade & $-0.060 *$ & 0.088 & -0.057 & 0.121 \\
\hline Retail Trade & -0.056 & 0.182 & $-0.096 * *$ & 0.024 \\
\hline Hospitality & -0.062 & 0.133 & -0.063 & 0.154 \\
\hline Transport and Storage & -0.040 & 0.376 & -0.027 & 0.572 \\
\hline Communication Services & $-0.086 *$ & 0.069 & -0.069 & 0.149 \\
\hline Property and Business Services & $-0.082 *$ & 0.061 & 0.015 & 0.781 \\
\hline Cultural and Recreational Services & -0.027 & 0.558 & -0.012 & 0.800 \\
\hline Personal Services & -0.033 & 0.464 & 0.039 & 0.445 \\
\hline Food Industry Sample (FIS) & -0.030 & 0.305 & -0.021 & 0.496 \\
\hline \multicolumn{5}{|l|}{ Base: 0-4 employees } \\
\hline 5-19 employees & 0.009 & 0.753 & $0.083^{* *}$ & 0.010 \\
\hline 20-199 employees & 0.040 & 0.298 & $0.132 * * *$ & 0.004 \\
\hline \multicolumn{5}{|l|}{ Base: Three or more competitors } \\
\hline No competitors & $-0.054 *$ & 0.050 & $-0.074 * *$ & 0.011 \\
\hline One or two competitors & -0.007 & 0.805 & -0.039 & 0.176 \\
\hline Log of total wages in 2004-05 & $0.014^{* *}$ & 0.045 & -0.004 & 0.596 \\
\hline Observed P & 0.192 & & 0.195 & \\
\hline Predicted P & 0.167 & & 0.168 & \\
\hline N Observations & 1513 & & 1408 & \\
\hline Pseudo R-squared & 0.115 & & 0.120 & \\
\hline
\end{tabular}

Notes: ${ }^{*} p<0.10,{ }^{* *} p<0.05,{ }^{* * *} p<0.01$ 
Table 5: Linear Regressions of the Change in Total Sales on the Type of Skill Shortage Encountered

\begin{tabular}{|c|c|c|c|c|}
\hline & \multicolumn{2}{|c|}{$\begin{array}{l}\text { One-year change in sales: } \\
2004-05 \text { to } 2005-06\end{array}$} & \multicolumn{2}{|c|}{$\begin{array}{c}\text { Two-year change in sales: } \\
2004-05 \text { to } 2006-07\end{array}$} \\
\hline & Coeff. & $\mathrm{P}>|\mathrm{t}|$ & Coeff. & $\mathrm{P}>|\mathrm{t}|$ \\
\hline \multicolumn{5}{|l|}{ Base: No shortage in any year } \\
\hline Shortage in Year 1 only & 4.96 & 0.193 & 5.58 & 0.423 \\
\hline Shortage in Year 2 only & $11.72 * *$ & 0.036 & -1.67 & 0.835 \\
\hline Shortage in Years 1 and 2 & $16.15^{* * *}$ & 0.002 & 13.50 & 0.146 \\
\hline Shortage in Year 3 only & & & -5.22 & 0.475 \\
\hline Shortage in Years 1 and 3 & & & 8.14 & 0.515 \\
\hline Shortage in Years 2 and 3 & & & 8.90 & 0.357 \\
\hline Shortage in all three Years & & & $22.99 *$ & 0.060 \\
\hline \multicolumn{5}{|l|}{ Base: Manufacturing } \\
\hline Agriculture & -5.62 & 0.216 & -4.56 & 0.573 \\
\hline Mining & 12.81 & 0.134 & $35.08 * * *$ & 0.007 \\
\hline Construction & 8.17 & 0.333 & 7.80 & 0.425 \\
\hline Wholesale Trade & 2.53 & 0.632 & 2.93 & 0.705 \\
\hline Retail Trade & -0.05 & 0.994 & -0.98 & 0.900 \\
\hline Hospitality & 6.25 & 0.433 & 0.36 & 0.968 \\
\hline Transport and Storage & 10.65 & 0.207 & 11.23 & 0.249 \\
\hline Communication Services & 10.56 & 0.215 & $30.09 * *$ & 0.029 \\
\hline Property and Business Services & 13.72 & 0.105 & $24.86^{*}$ & 0.073 \\
\hline Cultural and Recreational Services & -6.33 & 0.373 & -1.44 & 0.876 \\
\hline Personal Services & 4.40 & 0.533 & 7.88 & 0.532 \\
\hline Food Industry Sample (FIS) & -2.30 & 0.587 & 4.11 & 0.466 \\
\hline \multicolumn{5}{|l|}{ Base: 0-4 employees } \\
\hline 5-19 employees & $14.95 * * *$ & 0.001 & $15.50 * *$ & 0.024 \\
\hline 20-199 employees & $19.53 * * *$ & 0.001 & $26.09 * * *$ & 0.003 \\
\hline \multicolumn{5}{|l|}{ Base: Three or more competitors } \\
\hline No competitors & -0.32 & 0.944 & -1.26 & 0.854 \\
\hline One or two competitors & 1.32 & 0.733 & $-8.82 *$ & 0.077 \\
\hline Log of wages in 2004-05 & $-6.87 * * *$ & 0.000 & $-9.52 * * *$ & 0.000 \\
\hline Regression constant & $25.30 * * *$ & 0.002 & $40.56 * * *$ & 0.001 \\
\hline N Observations & 1447 & & 1300 & \\
\hline R-squared & 0.048 & & 0.054 & \\
\hline
\end{tabular}

Notes: ${ }^{*} p<0.10,{ }^{* *} p<0.05, * * * p<0.01$ 


\begin{tabular}{|c|c|c|c|c|c|c|c|c|c|c|c|c|}
\hline & \multicolumn{2}{|c|}{$\begin{array}{c}\text { (C) Existing } \\
\text { workforce longer } \\
\text { hours }\end{array}$} & \multicolumn{2}{|c|}{$\begin{array}{l}\text { (D) Subcontracted } \\
\text { or outsourced } \\
\text { work }\end{array}$} & \multicolumn{2}{|c|}{$\begin{array}{l}\text { (B) On-the-job or } \\
\text { internal training }\end{array}$} & \multicolumn{2}{|c|}{$\begin{array}{c}\text { (G) Reduce } \\
\text { outputs or } \\
\text { production }\end{array}$} & \multicolumn{2}{|c|}{$\begin{array}{l}\text { (F) Wages or } \\
\text { conditions } \\
\text { increased }\end{array}$} & \multicolumn{2}{|c|}{$\begin{array}{l}\text { (E) Employed on } \\
\text { short-term } \\
\text { contracts }\end{array}$} \\
\hline & $\mathrm{dF} / \mathrm{dx}$ & $\mathrm{P}>|\mathrm{z}|$ & $\mathrm{dF} / \mathrm{dx}$ & $\mathrm{P}>|\mathrm{z}|$ & $\mathrm{dF} / \mathrm{dx}$ & $\mathrm{P}>|\mathrm{z}|$ & $\mathrm{dF} / \mathrm{dx}$ & $\mathrm{P}>|\mathrm{z}|$ & $\mathrm{dF} / \mathrm{dx}$ & $\mathrm{P}>|\mathrm{z}|$ & $\mathrm{dF} / \mathrm{dx}$ & $\mathrm{P}>|\mathrm{z}|$ \\
\hline \multicolumn{13}{|l|}{ Cause of skill shortage } \\
\hline Specialist knowledge required & 0.006 & 0.912 & $0.151^{* * *}$ & 0.002 & $0.240 * * *$ & 0.000 & 0.027 & 0.578 & $0.101^{* *}$ & 0.042 & 0.031 & 0.365 \\
\hline Geographic location & 0.069 & 0.296 & 0.018 & 0.753 & 0.082 & 0.210 & 0.089 & 0.119 & 0.087 & 0.142 & -0.012 & 0.775 \\
\hline Wages or salaries too high & 0.071 & 0.233 & $0.183^{* * *}$ & 0.001 & $-0.107 *$ & 0.073 & 0.080 & 0.123 & $0.141^{* * *}$ & 0.009 & 0.017 & 0.661 \\
\hline Training availability & -0.011 & 0.858 & -0.007 & 0.896 & $0.113^{* *}$ & 0.060 & 0.078 & 0.142 & 0.046 & 0.382 & 0.057 & 0.162 \\
\hline Unsure of long-term demand & $0.238 * * *$ & 0.003 & $0.172^{* *}$ & 0.015 & -0.034 & 0.677 & $0.230 * * *$ & 0.002 & 0.028 & 0.692 & 0.050 & 0.351 \\
\hline Recruitment too slow & $0.106^{*}$ & 0.060 & $0.084 *$ & 0.095 & 0.083 & 0.152 & $0.130 * *$ & 0.011 & $0.132 * *$ & 0.010 & $0.083 * *$ & 0.024 \\
\hline Other causes (not specified) & 0.044 & 0.648 & 0.011 & 0.895 & -0.057 & 0.518 & $0.171^{*}$ & 0.038 & 0.108 & 0.233 & -0.013 & 0.831 \\
\hline \multicolumn{13}{|l|}{ Base: Tertiary sector } \\
\hline Primary sector & 0.027 & 0.709 & $0.126^{*}$ & 0.064 & -0.085 & 0.255 & 0.031 & 0.631 & 0.055 & 0.406 & $0.152 * * *$ & 0.004 \\
\hline Secondary sector & $0.144^{* *}$ & 0.033 & 0.100 & 0.102 & -0.082 & 0.219 & 0.040 & 0.520 & 0.028 & 0.641 & 0.050 & 0.294 \\
\hline Food Industry Sample (FIS) & -0.038 & 0.556 & $-0.141^{* *}$ & 0.011 & 0.034 & 0.608 & 0.044 & 0.447 & $-0.104 *$ & 0.063 & -0.010 & 0.785 \\
\hline \multicolumn{13}{|l|}{ Base: $0-4$ employees } \\
\hline 5-19 employees & $0.141^{*}$ & 0.088 & -0.098 & 0.158 & $0.194 * *$ & 0.023 & -0.076 & 0.253 & 0.068 & 0.362 & 0.057 & 0.244 \\
\hline 20-199 employees & 0.064 & 0.553 & -0.059 & 0.505 & $0.320 * * *$ & 0.004 & -0.009 & 0.923 & 0.005 & 0.960 & 0.068 & 0.288 \\
\hline \multicolumn{13}{|l|}{ Base: Three or more competitors } \\
\hline No competitors & -0.091 & 0.328 & -0.020 & 0.806 & -0.091 & 0.355 & 0.019 & 0.806 & -0.013 & 0.867 & -0.005 & 0.925 \\
\hline One or two competitors & -0.070 & 0.360 & 0.079 & 0.245 & -0.009 & 0.901 & -0.004 & 0.956 & -0.031 & 0.620 & 0.032 & 0.543 \\
\hline Log of wages in 2004-05 & 0.004 & 0.865 & 0.029 & 0.108 & -0.023 & 0.265 & -0.020 & 0.220 & $0.041^{* *}$ & 0.044 & -0.011 & 0.353 \\
\hline Observed P & 0.551 & & 0.263 & & 0.411 & & 0.255 & & 0.270 & & 0.135 & \\
\hline Predicted P & 0.556 & & 0.241 & & 0.397 & & 0.239 & & 0.252 & & 0.120 & \\
\hline N Observations & 392 & & 392 & & 392 & & 392 & & 392 & & 392 & \\
\hline Pseudo R-squared & 0.054 & & 0.103 & & 0.089 & & 0.090 & & 0.084 & & 0.071 & \\
\hline
\end{tabular}

Notes: ${ }^{*} p<0.10,{ }^{* *} p<0.05,{ }^{* * *} p<0.01$ 
${ }^{1}$ For a general discussion covering 19 countries on the view that what constitutes a skill shortage is not straightforward, see Cohen and Zaidi (2002).

${ }^{2}$ A recent addition to the range of available datasets is the New Zealand Business Operations Survey, which included a skills module in 2008 (see Mok et al. 2012). We are not aware of this dataset being used to study the performance consequences of skill shortages.

${ }^{3}$ This section draws on ABS (2009).

${ }^{4}$ Firms in the food industry were over-sampled at the request of the Australian Government. We retain these firms and include a dummy variable to distinguish them.

${ }^{5}$ Unfortunately, the BLD provides no information about the presence of trade unions, the gender or occupational composition of employees, or the use of immigrant workers by sampled firms.

${ }^{6}$ The measure of wages includes salaries, leave loadings and other allowances, but excludes regular superannuation payments and amounts that employees 'salary-sacrifice' from their pre-tax income.

${ }^{7}$ We do not weight these regression estimations. Instead, we include as control variables in our models those firm characteristics that were used to stratify the BLD, which accounts for the sampling design in a manner analogous to the use of weights (Winship and Radbill 1994).

${ }^{8}$ For instance, estimating the probability that a firm faces any kind of skill shortage would ignore the information on the different causes that is available in the BLD. Similarly, treating each cause separately would ignore the evidence that most skill shortage firms cite multiple causes (see Table 1). Finally, using data reduction methods, such as factor analysis, to group the causes, is not appropriate because the correlations between the individual causes are weak $(r<0.25$ in all cases).

${ }^{9}$ We do not present the results for two responses - 'more use of external training' and 'other (please specify)' - because their observed frequencies are too small to generate reliable estimates.

${ }^{10}$ Our analyses are (implicitly) conditional on firm survival. We have shown elsewhere (Healy et al., 2011: 48-50) that there is no significant association between skill shortages and the probability of firm survival.

${ }^{11}$ Nonetheless, some firms exhibit extreme volatility in the value of their year-to-year sales. We drop from the analysis a small number of these firms $(\mathrm{N}=26)$, with significant improvements in the fit of our regression equation. The excluded firms are predominantly small enterprises with 0-4 employees. Their average increase in sales was more than 1000 per cent over one year, and more than 2000 per cent over two years. 


\section{University Library}

\section{- M M I N E R VA A gateway to Melbourne's research publications}

Minerva Access is the Institutional Repository of The University of Melbourne

\section{Author/s:}

Healy, J;Mavromaras, K;Sloane, PJ

Title:

Adjusting to skill shortages in Australian SMEs

Date:

2015

Citation:

Healy, J., Mavromaras, K. \& Sloane, P. J. (2015). Adjusting to skill shortages in Australian SMEs. Applied Economics, 47 (24), pp.2470-2487. https:// doi.org/10.1080/00036846.2015.1008764.

Persistent Link:

http://hdl.handle.net/11343/116689 